Note

\section{Effects of Cellular Calcium and Magnesium Contents on Growth of Ionophore A23187-Treated Lactobacillus lactis}

\author{
Tapani Alatossava \\ Department of Genetics, University of Oulu, \\ SF-90570 Oulu, Finland
}

Received September 2, 1987

In this work the physiology of the divalent cations calcium $\left(\mathrm{Ca}^{2+}\right)$ and magnesium $\left(\mathrm{Mg}^{2+}\right)$ has been studied in the Gram-positive lactic acid bacteria Lactobacillus lactis, for this bacterium is well-adapted to high external calcium content, namely milk, and because many bacteriophages of lactic acid bacteria have been shown to require calcium for proliferation. ${ }^{1,2)}$ On the other hand, magnesium is the major intracellular divalent cation required for the growth of all cells. ${ }^{3)}$

Cellular $\mathrm{Ca}^{2+}$ and $\mathrm{Mg}^{2+}$ contents of $L$. lactis were manipulated with the divalent cation-specific ionophore $\mathrm{A} 23187^{4)}$ and $\mathrm{CaCl}_{2} / \mathrm{MgCl}_{2}$ supplements in the growth medium Lactobacilli MRS Broth (Difco), and the effects of these treatment on $L$. lactis growth were revealed. It is known that $\mathrm{A} 23187$ induced $\mathrm{Ca}^{2+}$ and $\mathrm{Mg}^{2+}$ fluxes through the cell membrane via two proton exchanges. ${ }^{5)}$ The magnitude and direction of cation fluxes and consequently their effects on bacterial growth are affected by several factors such as ionophore concentration and magnitudes of divalent cation and proton $\left(\mathrm{H}^{+}\right)$gradients across the cell membrane. ${ }^{6)}$

Figure 1 shows a summary of the growth test experiments. As shown, it was possible to restore the growth of A23187-treated L. lactis cells, if enough $\mathrm{MgCl}_{2}(10 \mathrm{~mm}$ or more) was present in the growth medium. The dualistic behaviour of a $\mathrm{CaCl}_{2}$ supplement with $\mathrm{MgCl}_{2}$ on L. lactis growth is obvious: at lower external $\mathrm{Ca}^{2}$ : concentrations (less than $20 \mathrm{~mm}$ ), $\mathrm{Ca}^{2+}$ showed synergism with $\mathrm{Mg}^{2+}$, but it was toxic when more than $20 \mathrm{mM} \mathrm{CaCl}_{2}$ was present in the growth medium (Fig. 1). To confirm this unexpected feature of $\mathrm{Ca}^{2+}$ and further to try to understand its basis, a set of experiments including cellular $\mathrm{CA}^{2+}$ and $\mathrm{Mg}^{2+}$ content measurements was done (Table I). As shown (control 2 and exp. 1 in Table I), an A23187-mediated reduction of cellular $\mathrm{Mg}^{2+}$ content to one third of the control level completely prevented bacterial growth. This occurred even in the presence of $20 \mathrm{mM} \mathrm{MgCl}_{2}$ in the growth medium (the $\mathrm{Ca}^{2+}$ concentration of unsupplemented MRS medium is about $1 \mathrm{mM}$ ). With higher concentrations of $\mathrm{MgCl}_{2}(40 \sim 60 \mathrm{mM})$, it was possible to diminish (but not to prevent) A23187-induced $\mathrm{Mg}^{2+}$ leakage by almost a half (about $60 \%$ of control value) and bacterial growth was then no longer considerably affected (control 2 and exps. 2 and 3 in Table I). When the growth medium for A23187-treated cells was supplemented with varying concentrations of $\mathrm{CaCl}_{2}$ (up to $40 \mathrm{~mm}$ ) together with $20 \mathrm{mM} \mathrm{MgCl}_{2}$, the cellular $\mathrm{Ca}^{2+}$ content increased linearly with increasing external $\mathrm{CaCl}_{2}$ concentrations, but the cellular $\mathrm{Mg}^{2+}$ content was constantly about one third of the control $\mathrm{Mg}^{2+}$ level, as might be expected (controls 1 and 2 and exps. $4 \sim 7$ in Table I). Again the dualistic feature of $\mathrm{Ca}^{2+}$ on bacterial growth after A23187 treatment was evident: when $\mathrm{CA}^{2+}$ was present at concentrations of $20 \mathrm{~mm}$ or less in the growth medium, bacterial growth was promoted (exps. 4 and 5), but at higher external concentrations (more than $20 \mathrm{~mm}$ $\mathrm{CaCl}_{2}$ ), strong growth inhibition was observed (exps. 6 and 7). The growth of L. lactis continued if about half of the original $\mathrm{Mg}^{2+}$ content was preserved after A23187induced $\mathrm{Mg}^{2+}$ leakage. Even one third of the control $\mathrm{Mg}^{2+}$ content was enough for bacterial growth, if an appropriate $\mathrm{Ca}^{2+}$ influx accompanied $\mathrm{A} 23187$ treatment (Table I).

The results show that $\mathrm{Ca}^{2+}$ cannot completely substitute for the functions of $\mathrm{Mg}^{2+}$ in L. lactis, although it shows some synergism with $\mathrm{Mg}^{2+}$ (Fig. 1 and Table I). It

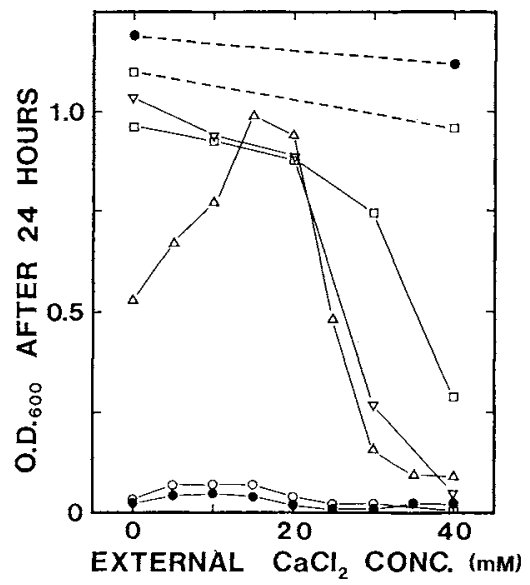

FIG. 1. The Dualistic Effects of $\mathrm{CaCl}_{2}$ Supplement with $\mathrm{MgCl}_{2}$ in Growth Medium on the Growth of A23187Treated Lactobacillus lactis.

$100 \mu 1$ of $L$. lactis culture in logarithmic growth phase in MRS medium were added to $5 \mathrm{ml}$ MRS medium supplemented with different concentrations of $\mathrm{CaCl}_{2}$ and $\mathrm{MgCl}_{2}$ and with $1.5 \mu \mathrm{g} / \mathrm{ml} \mathrm{A} 23187$ (solid line). In controls (dotted line), an appropriate volume of ethanol (ionophore solvent) was used. Cultures were incubated for $24 \mathrm{hr}$ at $37^{\circ} \mathrm{C}$ and the turbidities of the cultures were measured at $600 \mathrm{~nm}\left(\mathrm{OD}_{600}\right)$. Symbols for $\mathrm{MgCl}_{2}$ concentrations in MRS growth medium: $(\bullet)$, no $\mathrm{MgCl}_{2} ;(\bigcirc), 2 \mathrm{mM} \mathrm{MgCl}_{2}$; $(\triangle), 10 \mathrm{mM} \mathrm{MgCl}_{2} ;(\nabla), 20 \mathrm{mM} \mathrm{MgCl} ;(\square) 40 \mathrm{mM} \mathrm{MgCl}_{2}$. 
Table I. Effects of External Magnesium and Calcium Concentrations on Cellular Magnesium and Calcium Contents AND ON THE Growth of Lactobacillus lactis Cultures after A23187 Treatment

Lactobacillus lactis was grown in MRS medium supplemented with $20 \mathrm{~mm} \mathrm{MgCl}_{2}$ or $\mathrm{CaCl}_{2}$ at $37^{\circ} \mathrm{C}$. After an $\mathrm{OD}_{600}$ of 0.3 was reached, $3 \mu \mathrm{g} / \mathrm{ml} \mathrm{A} 23187$ (exps. I 8) and different concentrations of $\mathrm{MgCl}_{2}$ or $\mathrm{CaCl}_{2}$ were added. In controls, instead of A23187 an equal amount of ionophore solvent ethanol was added. After 40 minutes, samples were withdrawn for cellular $\mathrm{Mg}$ and $\mathrm{Ca}$ measurement. The growth of bacterial cultures was followed by measuring an increase in $\mathrm{OD}_{600} 24 \mathrm{hr}$ after $\mathrm{A} 23187$ addition. Identification of cellular cation content of $L$. lactis has been described elsewhere. ${ }^{7)}$

\begin{tabular}{|c|c|c|c|c|c|c|c|}
\hline \multirow{2}{*}{ Experiment } & \multicolumn{3}{|c|}{ External concentration (mM) } & \multicolumn{3}{|c|}{ Cellular cation content (nimol/mg dw) } & \multirow{2}{*}{ Increase of $\mathrm{OD}_{600}$} \\
\hline & $\mathrm{Mg}$ & $\mathrm{Ca}$ & Sum & $\mathrm{Mg}$ & $\mathrm{Ca}$ & Sum & \\
\hline Control 1 & 2 & 20 & 22 & 195 & 25 & 220 & 0.9 \\
\hline Control 2 & 20 & 1 & 21 & 160 & $<10$ & $160 \sim 170$ & 0.9 \\
\hline Exp. & 20 & 1 & 21 & 55 & $<10$ & $55 \sim 65$ & 0.1 \\
\hline Exp. & 40 & 1 & 41 & 90 & $<10$ & $90 \sim 100$ & 0.8 \\
\hline Exp. & 60 & 1 & 61 & 100 & $<10$ & $100 \sim 110$ & 0.8 \\
\hline Exp. & 20 & 10 & 30 & 60 & 20 & 80 & 0.45 \\
\hline Exp. & 20 & 20 & 40 & 45 & 50 & 95 & 0.55 \\
\hline Exp. & 20 & 30 & 50 & 50 & 60 & 110 & 0.2 \\
\hline Exp. & 20 & 70 & 60 & 55 & 100 & 155 & 0.15 \\
\hline Exp. & 2 & 20 & 22 & 20 & 200 & 220 & 0.05 \\
\hline
\end{tabular}

is possible that $\mathrm{Ca}^{2+}$ is able to directly take care of some of the functions originally carried out by $\mathrm{Mg}^{2+}$ in L. lactis. However, we cannot exclude the possibility that, at least partially, the synergistic effect of $\mathrm{Ca}^{2+}$ is caused by the A23187-mediated $\mathrm{Ca}^{2+} / 2 \mathrm{H}^{+}$exchange, ${ }^{4)}$ which might help the cell in the re-balance of intracellular $\mathrm{pH}$, disturbed by $\mathrm{Mg}^{2+}$ efflux concomitant with $\mathrm{H}^{+}$influx. The results show that it is possible to increase cellular $\mathrm{Ca}^{2+}$ content to a considerable extent (up to $40 \sim 50 \mathrm{nmol} / \mathrm{mg}$ dry weight, Table I) without any drastic effect on $L$. lactis growth. The toxic effects of high cellular $\mathrm{Ca}^{2+}$ contents (more than $50 \mathrm{nmol} / \mathrm{mg}$ dry weight, Table I) may be a result of the limited solubility of $\mathrm{Ca}^{2+}$ in cellular sap. Possibly the formation of intracellular $\mathrm{Ca}^{2+}$ phosphate precipitate may be involved.

Acknowledgments. This work has been done during my visit at the Department of Microbiology, Biozentrum, University of Basel, Switzerland. I would like to thank Helga Jütte for her excellent technical assistance, Dr. Hans Seiler (Institute of Analytical Inorganic Chemistry,
University of Basel) for analysing the cations by AAS, and Prof. Edward Kellenberger for his advice during this study. The visit was supported by a grant from the Academy of Finland.

\section{REFERENCES}

1) P. M. Roundtree, J. Gen. Microbiol., 12, 275 (1955).

2) K. Watanabe and S. Takesue, J. Gen. Virol., 17, 19 (1972).

3) S. Silver and R. D. Perry, Adv. Chem., 197, 454 (1981).

4) P. W. Reed and H. A. Lardy, J. Biol. Chem., 247, 6970 (1972).

5) D. R. Pfeiffer, R. W. Taylor and H. A. Lardy, Ann. N. Y. Acad. Sci., 307, 402 (1978).

6) T. Alatossava, H. Jütte, A. Kuhn and E. Kellenberger, J. Bacteriol., 162, 413 (1985).

7) T. Alatossava, H. Jütte and H. Seiler, J. Gen. Virol., 68, 1525 (1987). 